NBER WORKING PAPER SERIES

STOCK ISSUES AND INVESTMENT POLICY WHEN FIRMS

HAVE INFORMATION THAT INVES'TORS DO NOT HAVE

\author{
Stewart C. Myers \\ Nicholas S. Majluf \\ Working Paper No. $\underline{884}$ \\ NATIONAL BUREAU OF ECONOMIC RESEARCH \\ 1050 Massachusetts Avenue \\ Cambridge MA 02138
}

April 1982

Research support from the Office of Naval Research is gratefully acknowledged. The research reported here is part of the NBER's research program in Taxation. Any opinions expressed are those of the authors and not those of the National Bureau of Economic Re search. 


\title{
STOCK ISSUES AND INVESTMENT POLICY WHEN FIRMS HAVE INFORMATION THAT \\ INVESTORS DO NOT HAVE
}

\begin{abstract}
This paper describes corporate investment and financing decisions when managers have inside information about the value of the firm's existing investment and growth opportunities, but cannot convey that information to investors. the firm may for otherwise perfect and efficient. In these circumstances, Finance it. The galuable investment opportunity rather than issue stock to information. If stock is to issue cannot fully convey the managers' special slack are valuable if is issued, stock price falls. Liquid assets or financial The paper also suggests reduce the probability or extent of stock issues. choice of capital structure.
\end{abstract}

\author{
Stewart C. Myers \\ Sloan School of Management \\ MIT/E 52-243F \\ 50 Memorial Drive \\ Cambridge, MA \\ (617) $253-6696$ \\ Nicholas J. Majluf \\ Universidad Catolica de Chile \\ Escuela de Ingenieria \\ Casilla 114-D \\ Santiago, CHILE
}


STOCK ISSUES AND IXVESTIENT POLICY THEN

FIRIS HAVE INFORIATION THAT INVESTORS DO NOT HAVE

Stewart C. Myers and Nicholas S. Majluf $\underline{1 /}$

Consider a firm that has assets in place and also a valuable real investment opportunity. However, it has to issue common shares to raise part or all of the cash required to undertake the investment project. If it does not launch the project promptly the opportunity will evaporate. There are no taxes, transaction costs or other capital market imperfections.

Finance theory would advise this firm to evaluate this investment opportunity as if it already had plenty of cash on hand. In an efficient capital market, securities can always be sold at a fair price; the net present value of selling securities is always zero because the cash raised exactly balances the present value of the liability created. Thus, the decision rule is: take every positive-NPV project, regardless of whether internal or external funds are used to pay for it.

What if the firm's managers know more about the value of its assets and opportunities than outside investors do? As we will show, nothing fundamental is changed so long as managers always follow the decision rule just noted. The shares investors buy will be correctly priced on average, althougi a particular issue will be over or underpriced. The manager's inside information creates a side bet between old and new stockholders but the equilibrium issue price is unaffected.

However, if managers have inside information there must be some cases in which that information is so favorable that management, if it acts in the interest of the old stockholders, will refuse to issue shares 
even if it means passing up a good investment opportunity. That is, the cost of issuing shares at a bargain price may outweigh the project's NPV. This possibility makes the problem interesting: investors, aware of their relative ignorance, will reason that a decision not to issue shares signals "good news." The news conveyed by an issue is bad or at least less good. This affects the price investors are willing to pay for the issue, which in turn, affects the issue-investment decision.

The problem is to figure out the equilibrium share price conditional on the issue-investment decision, assuming rational investors, and also a rational firm which bases the issue-investment decision on the price it faces: This paper addresses that problem, and solves it under reasonable simplifying as sumptions.

The assumptions are set out and discussed in Section 1 . This section also contains two numerical examples. A general formulation and solution is given in section 3 . The last section describes extensions of our model and summarizes its implications.

We defer the customary introductory review of the literature until the end of Section 2, after our assumptions have been more fully explained.

\section{ASSUMPTIONS AND EXAMPLES}

We assume the firm (i.e., its managers) has information that investors do not have, and that both managers and investors realize this. We take this infornation differential as given--a fact of life. We side-step the question of how much information managers should release, except to note the underlying assumption that transmitting information is costly. Our problem disappears if managers can costlessly convey their special information to the market. 
The firm has one existing asset and one opportunity requiring investment $I$. Tine investment $c$ an be financed by issuing stock, drawing down the firm's cash balance or selling marketable securities. The sum of cash on hand and marketable securities will be referred to as financial slack (S).

Financial slack should also include "debt capacity," defined as the amount of default-risk free debt the firm can issue. (Discussion of risky debt is deferred to Section 3.) However, it's simpler for our purposes to let the firm use risk-free borrowing to reduce the required investment $I$. We may thus interpret $I$ as required equity investment.

The investment opportunity evaporates if the firm does not go ahead at time $t=0$. If $S<I$, going ahead requires a stock issue of $E=I-S$. Also, the project is "all or nothing"--the firm can't take part of it.

We assume capital markets are perfect and efficient with respect to publicly available information. There are no transaction costs in issuing stock.

We also assume that market value of the firm's shares equals their expected future value conditional on whatever information the market has. The future values could be discounted for the time value of money without changing anything essential. 2/ Discounting for risk is unnecessary, because the only uncertainty important in this problem stems from managers' special information. Investors at time $t=0$ do not know whether the firm's stock price will go up or down when that special information is revealed at $t=1$. However, this risk is likely to be diversifiable. $3 /$

We can now give a detailed statement of who knows what when. 


\section{A Three-Date Model}

1. There are three dates, $t=1,0=x \mathrm{~d}+1$. At $t=-1$ the market has the same information the managezent does. At $t=0$, management receives additional information about the value of the firm's asset-inplace and investment opportunity, and upcazes their values accordingly. The market does not receive this information until $t=+1$.

2. The value of the asset-in-place $\equiv t t=-1$ is $\bar{A}=E(\tilde{A})$; the distribution of $\widetilde{A}$ represents the asset's cossible (updated) values at $t=0$. Management's updated estimate at $t=0$ is a. That is, a is the realization of $\tilde{A} . \underline{4}$

3. The net present value (NPV) at $t=-1$ of the investment opportunity is $\bar{B}=E(\widetilde{B})$. The distribution of $\overrightarrow{3}$ represents the asset's possible updated NPVs at $t=0$. Manageme:t's updated estimate at $t=0$ is $b$, the realization of $\tilde{B}$.

4. Negative values for $a$ and $b$ are ruled out. This makes sense for the asset-in-place because of ligited liability. It makes sense for the investment opportunity because the opportunity is discarded if it turns out to have a negative NPV at $t=0$. In other words, the distribution of $\widetilde{B}$ is truncatec at zero.

5. Management acts in the interest of the "old" shareholders, those owning shares at $t=-1$. That is, they Eximize $V_{O}^{o l d}=V(a, b, E)$. However, the market value of the old stociholders' shares will not generally equai $V^{o l d}$. Let $P$ be the marke= value. $P$ reflects the distribution of $\widetilde{A}$ and $\widetilde{\mathrm{B}}$ and also managerent's decision to issue shares or not. Let 


$$
\begin{aligned}
P^{\prime}= & \text { market value at } t=0 \text { of old stockholders } \\
& \text { shares if stock is issued. } \\
P= & \text { market value at } t=0 \text { if stock is not issued. }
\end{aligned}
$$

6. Slack, $S$, is fixed and known by both managers and the market.

The information available to management and the market is summarized below:

\section{Date:}

$$
\underline{t}=-1
$$

$$
\underline{t}=\underline{0}
$$

\begin{tabular}{|c|c|c|c|}
\hline Managers & $\begin{array}{l}\text { Disfributions } \\
\text { of } \overparen{A} \text { and } \vec{B} ; S\end{array}$ & $a, b ; S$ & $\mathrm{a}, \mathrm{b}$; remaining $\mathrm{s}$, if any \\
\hline Market & $\begin{array}{l}\text { Distributions } \\
\text { of } \AA \text { and } \overrightarrow{\mathrm{B}}: \mathrm{S}\end{array}$ & $\begin{array}{l}\text { Distributions } \\
\text { of } \AA \text { and } \vec{B} ; S ; \\
\text { also } E \text {, either } \\
E=0 \text { or } \\
E=I-S\end{array}$ & $a, b$; remaining $S$, if any \\
\hline
\end{tabular}

$\underline{t}=+1$

Information available to:

\section{Two Examples}

The following two examples should give a better understanding of the problem just posed and the steps required to solve it. In the first example, the firm always issues stock and goes ahead vith a positive NPV opportunity. In the second example it may not.

First example. There are two equally probable states of nature. The true state is revealed to management at $t=0$ and to investors at $t=+1$. Asset values are:

\section{$\underline{\text { State } 1} \quad \underline{\text { State } 2}$}

Asset-in-place

Investment Opportunity (NPV)
$a=150$
$a=50$
$\mathrm{b}=100$
$\mathrm{b}=10$ 
The firm has no cash or marketable securities $(S=0)$. The investment opportunity requires $I=100$, so the firm must issue stock to raise $E=100$ if it goes ahead.

We now examine a trial solution assuming the firm issues stock and undertakes the project regardless of whether the favorable or unfavorable state occurs. In that case $P^{\prime}=155$ because $\bar{A}+\bar{B}=155$.

In state 1 , the true value of the firm, including 100 raised from the stock issue, is 350. That is $v \equiv \mathrm{v}^{\text {old }}+\mathrm{v}^{\text {new }}=350$. The market value is $P^{\prime}+E$ (the old shares' market value is $P^{\prime}$, the new shares' $E$ ). Thus

$$
\begin{aligned}
& \mathrm{v}^{\text {old }}=\frac{\mathrm{P}^{\prime}}{\mathrm{P}^{\prime}+\mathrm{E}} \quad \mathrm{V}=\frac{155}{255} \cdot 350=212.75 \\
& \mathrm{~V}^{\text {new }}=\frac{\mathrm{E}}{\mathrm{P}^{\prime}+\mathrm{E}} \quad \mathrm{V}=\frac{100}{255} \cdot 350=137.25 .
\end{aligned}
$$

In state 2 ,

$$
\begin{aligned}
\mathrm{v} & =\mathrm{v}^{\mathrm{old}}+\mathrm{v}^{\mathrm{new}}=160 \\
\mathrm{v}^{\mathrm{old}} & =\frac{155}{255} \cdot 160=97.25 \\
\mathrm{v}^{\text {new }} & =\frac{100}{255} \cdot 160=62.75
\end{aligned}
$$

Note that both old and new shares are correctly priced to investors, who regard the two states as equally probable.

$$
\begin{aligned}
& P^{\prime}=\frac{1}{2}(212.75+97.25)=155 . \\
& E^{\prime}=\frac{1}{2}(137.25+62.75)=100 .
\end{aligned}
$$


Because the firn issues stock in both states, the decision to issue tells investors nothing about the true state.

This trial solution is the equilibrium solution, because issuing stock and going ahead with the project leaves the old stockholders better off regardless of the true state:

$\begin{array}{lcc}\begin{array}{l}\text { Payoff } \\ \mathrm{v}^{\text {old }} \text { in } \\ \text { state } 1\end{array} & \begin{array}{c}\text { Issue and } \\ \text { invest }(\mathrm{E}=100)\end{array} & \begin{array}{c}\text { Do nothing } \\ (\mathrm{E}=0)\end{array} \\ \begin{array}{l}\text { vold in } \\ \text { state 2 }\end{array} & 212.75 & 150 \\ \end{array}$

In this example the firm has no use for financial slack. If it had, say, 100 in $\operatorname{cash}(S=100)$ it would make exactly the same investment decisions. The payoffs to old stockholders, after subtracting their extra 100 investment in the firm's cash balance, would be:

$\begin{array}{lcc}\begin{array}{lc}\text { Payoff } \\ \text { vold in }\end{array} & \text { Invest } & \text { Do nothing } \\ \text { state } 1 & 250 & 150 \\ \text { v }^{\text {old in }} & & \\ \text { state } 2 & 60 & 50\end{array}$

The state payoffs differ, but expected payoff is identical: $\frac{1}{2}(250+60)=155$.

Second example. Let the investment opportunity's NPV be +20 in state 1 . It was 100 in the first example.

State 1

Asset-in-place

Investment Opportunity (NPV)
$a=150$
$a=50$
$\mathrm{b}=20$
$b=10$ 
Thus $\bar{A}+\bar{B}=115$, and $\mathrm{P}^{\prime}=115$ if the firm issues stcck in

both states. Let's start by assuming it does.

In state 1 ,

$$
\begin{aligned}
v & =v^{\text {old }}+v^{\text {new }}=270 \\
v^{o l d} & =\left(\frac{P^{\prime}}{P^{\prime}+E}\right) v=\frac{115}{215} \cdot 270=144.42 \\
v^{\text {new }} & =\left(\frac{E}{P^{\prime}+E}\right) v=\frac{100}{215} \cdot 270=125.58
\end{aligned}
$$

In state 2 ,

$$
\begin{aligned}
\mathrm{v} & =\mathrm{v}^{\text {old }}+\mathrm{v}^{\text {new }}=160 \\
\mathrm{v}^{\text {old }} & =\frac{115}{215} \cdot 160=85.58 \\
\mathrm{v}^{\text {new }} & =\frac{100}{215} \cdot 160=74.42
\end{aligned}
$$

Note that $P^{\prime}=\frac{1}{2}(144.42+85.58)=115$, and $E=\frac{1}{2}(125.58+74.42)=100$. Now look at the payoffs to old stockholders:

$\begin{array}{lcc}\text { Payoff } & \begin{array}{c}\text { Issue and } \\ \text { invest }(E=100)\end{array} & \begin{array}{c}\text { Do nothing } \\ (E=0)\end{array} \\ \begin{array}{l}\mathrm{v}^{\text {old }} \text { in } \\ \text { state } 1\end{array} & 144.42 & 150 \\ \text { v } & & 50 \\ \text { state } 2 & 85.58 & \end{array}$

This is somewhat more complicated. With these payoffs, tie optimal 
strategy is to issue and invest only in state 2 , because in state 1 , the market value of the old stockholder's shares is lower when shares are issued. But if the firm follows this strategy, issuing stock signals state 2 and $P^{\prime}$ drops to 60. The equilibrium payoffs are those circled below:

$\begin{array}{lcc}\text { Payoffs } & \begin{array}{c}\text { Issue and } \\ \text { invest }(E=100)\end{array} & \begin{array}{c}\text { Do nothing } \\ (\mathrm{E}=0)\end{array} \\ \begin{array}{l}\text { vold in } \\ \text { state } 1\end{array} & 144.42 & 150) \\ \text { v }^{\text {old in }} & & \end{array}$

Thus the firm passes up a good investment project $(\mathrm{NPV}=+20)$ in state 1. Its market values at $t=0$ will be $P^{\prime}=60$ (state 2) and $P=150$ (state 1 ). The average payoff to old stockholders is $\frac{1}{2}(150+60)=105$. There is a loss of 10 in firm value - i.e., at $t=-1, v=105$ vs. 115 in the first exampje.

In this example, the firm is better off with cash in the bank. If $S=100$, the payoffs, net of the additional cash investment, are

$\begin{array}{lcc}\begin{array}{lc}\text { Payoff } \\ v^{\text {old }} \text { in }\end{array} & \text { Invest } & \text { Do nothing } \\ \text { state } 1 & 170 & 150 \\ \text { vold in } & & \\ \text { state } 2 & 60 & 50\end{array}$

In this case there appears to be an incentive to leave the cash ${ }^{\circ}$ in the bank, and issue stock in state 2. But that action would immediately 
reveal the true state, forcing $P^{\prime}$ down to 60 . If the firm does not have to issue stock to undertake the project, smart investors will assume the worst if it does issue.

\section{Discussion}

The conventional rationale for holding financial slack-- cash, liquid assets, or unused borrowing power-- is that the firm doesn't want to have to issue stock on short notice in order to pursue a valuable investment opportunity. Managers point to the red tape, delays and underwriting costs encountered in stock issues. They also typically say, "We don't want to be forced to issue stock when our firm is undervalued by the market."

A financial economist would respond by asking, "Managers may have superior information, but why should that be a disadvantage? If we admit that the firm is sometimes undervalued, then sometimes it must be overvalued. Why can't firms take advantage of the market by issuing securities only when the firm is overpriced?"

Our examples suggest answers for these questions: slack has value in example 2 , because without it the firm is sometimes unwilling to issue stock and therefore passes up a good investment opportunity. Slack does not allow the firm to take advantage of investors by issuing only when stock is overvalued. Firms can get away with that only when they do not nave slack sufficient to cover their investment requirements. 
The value of slack of course disappears if the firm can costlessly convey the true values $a, b$ to the market. One way to justify our contrary assumption is to think of cases in which values depend on proprietary information which, if released to the market, vould be released to competitors also, consequently reducing $a$ and/or $b$.

The firm cannot convey that information by saying, "We have great prospects but we can't tell you the details." In our model, the firm always has the incentive to do this, so such statements carry no information. The firm has to supply verifiable detail sufficient to indicate the true state of nature. The costs of supplying, absorbing and verifying this detail may be significant.

Slack is clearly unnecessary if the firm has a "private line" to existing stockholders. However, private communication to all old stockholders would be difficult and also illegal for publicly held firms. Slack is also unnecessary if the firm can compel its old stockholders to buy and hold any new issue; in this case the conflict between old and new stockholders does not exist. $5 /$

$\underline{\text { Related Work }}$

Our problem is similar to the one addressed by Ackerloff [1], who showed how markets can break down when potential buyers cannot verify the quality of the product they are offered. Faced with the risk of buying a lemon, the buyer will demand a discount, which in turn discourages the potential sellers who do not have lemons. But in our paper, the seller is not offering a single good, but a partial claim on two, the asset-in-place and the new project. Moreover, the seller gives up one of them (the new project) if the partialcclaim is not sold. Without this more complex structure we would have little to say, beyond noting that securities can be lemons too. 
Ackerloff's paper was one of the first investigations of the economics of unevenly distributed information. The assumption of differential information underlies extensive recent work on agency costs, signalling, adverse selection, etc. A detailed review of all that is not needed here. However, several articles are directly relevant to our problem:

1. Campbell [4] assumes that firms have proprietary information that would be costly to convey to the rarket. He describes tine resulting financing difficulties and possible remedies. His main point is to provide a new rationale for debt financing througn financial intermediaries. It may for example, be possible to reval proprietary information to a bank without revealing it to competitors; the bank could then finance a new project on terms which are fair to old stociholders.

However, Campell does not consider what happens if a firm with proprietary information does attempt a public issue. He presents no formal equilibrium model of security pricing and of the financing and investment decisions of the firm.

2. Leland and Pyle [11] consider an entrepreneur seeking additional equity financing for a single venture. The entrepreneur knows the project's expected return but outside investors do not. However, the outside investors observe the fraction of the entrepreneur's personal wealth committed to the project, and set their valuation accordingly. The greater the entrepreneur's willingness to take a personal stake in the project, the more inventors are willing to pay for their share of it.

3. Bhattacharya and Ritter [3] pose a problem similar to ours, but end up asking a different question. We fix the extent of managers' inside information and examine the equilibrium issue-investment decision. They ask how much information the firm should reveal, assuming that each 
revelation provides information to competitors as well as inventors, and therefore reduces the value of the firm. They show that the firm may be able to convey its true value to investors without revealing everything its competitors would like to know. However, their search for signalling equilibria carries them a long way from this paper's analysis.

4. Rendleman [13] also sets a problem similar to ours. His investors may over- or undervalue the firm's assets or investment opportunities or misassess its risk. He focuses on the choice between debt and equity financing, but does not derive a full equilibrium model. For example, he shows that undervalued firms will typically prefer debt, but does not model the market's response to the firm's choice of debt over equity. In general management's choice of financing must convey information about the firm's intrinsic value and actual risk. Of course the signal would be more complex than in our case, in which the firm has only two choices: issue equity or nothing. A full equilibrium model with more than one financing instrument is beyond us, at least for the time being. We offer some limited observations on the debt-equity choice later in the paper.

5. There are other theoretical papers exploring how managers' inside information is signalled to investors. They include Bhattacharya's 
work on dividend policy [2], and Ross's papers on "financial incentive signalling" $[14,15]$, in which a manager's employment contract leads him to convey information about the firm's prospects through a choice of its capital structure.

2. THE FORIAL MCDEL

In this section, we give a formal statement and solution of the model introduced in section 1 . We assume $0 \leq S<I$ so that some or all of the project must be financed by a stock issue. By varying slack $\mathrm{S}$, we vary the size of the required issue, $E=I-S$.

If the firm, knowing the true values $a$ and $b$, does not issue, it forfeits the investment opportunity, so $\mathrm{V}^{\mathrm{old}}=\mathrm{S}+\mathrm{a}$. The slack remains in cash or liquid assets. If it does issue and invest, $E=I-S$ and 


$$
v^{\text {old }}=\frac{P^{\prime}}{P^{\prime}+E}(E+S+a+b) \quad \text {. }
$$

old stockholders are better off if the firm issues only when

$$
S+a<\frac{P^{\prime}}{P^{\prime}+E}(E+S+a+b)
$$

or when

$$
\begin{gathered}
\frac{E}{\mathrm{P}^{\prime}+E}(\mathrm{~S}+\mathrm{a})<\frac{\mathrm{P}^{\prime}}{\mathrm{P}^{\prime}+E}(E+\mathrm{b}) \\
\left(\begin{array}{l}
\text { Share of existing } \\
\text { asset and slack } \\
\text { going to new } \\
\text { stockholders }
\end{array}\right)<\left(\begin{array}{l}
\text { Share of increment } \\
\text { to firm value obzained } \\
\text { by old stockholders }
\end{array}\right)
\end{gathered}
$$

The condition can also be written:

$$
\frac{E}{P^{\prime}}(S+a)<E+b \quad \text {. }
$$

Thus the line

$$
\frac{E}{P^{\prime}}(S+a)=E+b
$$

divides the joint probability distribution of $\tilde{A}$ and $\tilde{B}$ into two regions, as shown in Figure 1 . If the actual outcome $a, j$ falls in region $M^{\prime}$, the firm issues and invests. If the outcome zalls in region $M$, the firm does notning.

Remember that the joint probability distribution of $a$ and $b$ is restricted to the Northeast quadrant of Figure 1 . Region if' is at the top left of this quadrant. The firm issues when $b$ is high and a 


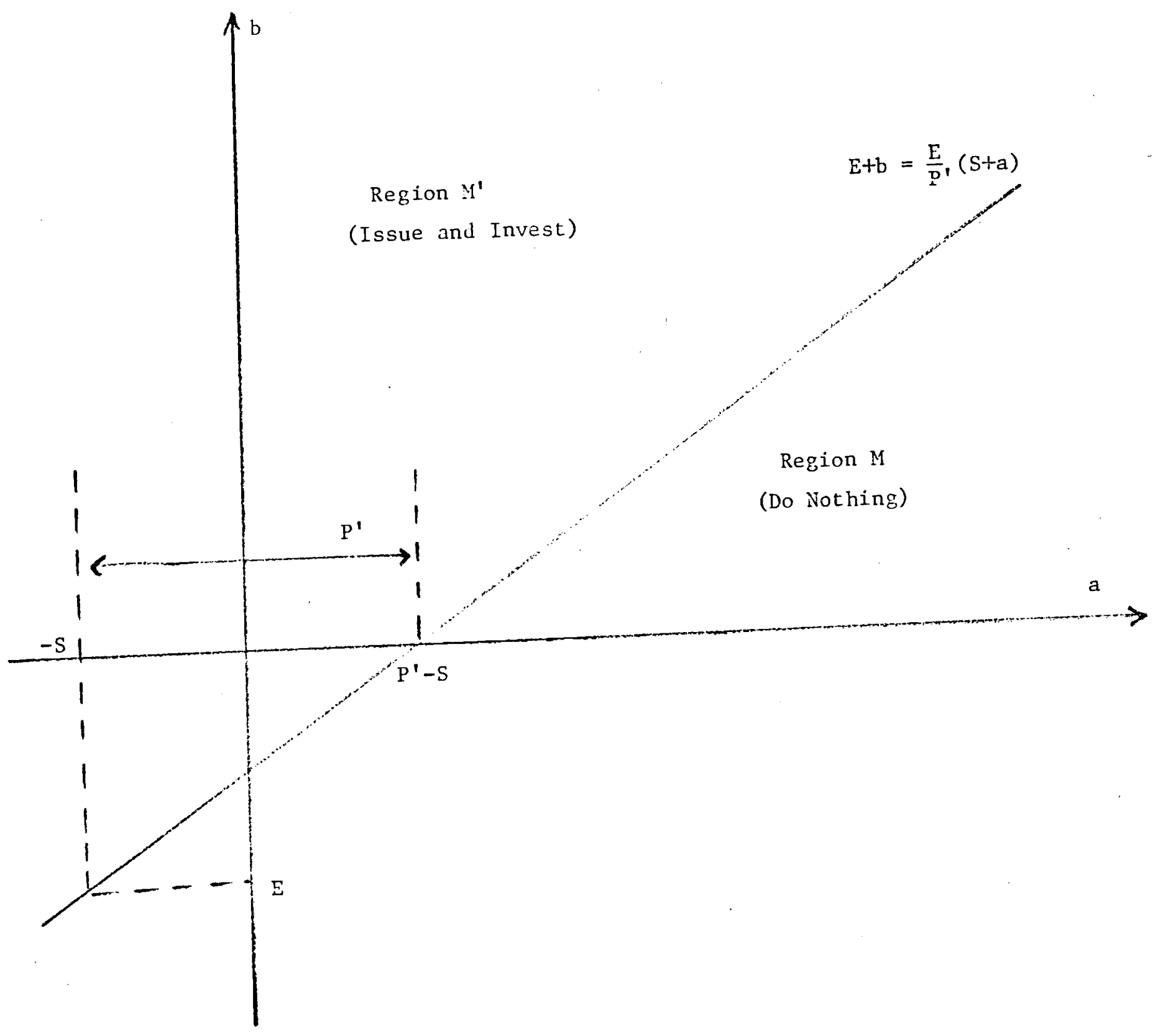

Figure 1. The issue-investmentdecision. 
is low. The higher $b$ is, the more the firm loses by not issuing. The lower a is, the more attractive the issue price $\mathrm{P}^{\prime}$. Of course $P^{\prime}$ itself clepends on the probability densities of $(\tilde{A}, \tilde{B})$ in the regions $M$ and $M^{\prime}$. The stock issue will be fairly priced to investors if

$$
P^{\prime}=S+\bar{A}\left(M^{\prime}\right)+\bar{B}\left(M^{\prime}\right)
$$

where $\bar{A}\left(M^{\prime}\right) \equiv E(\tilde{A} \mid E=I-S)$ and $\bar{B}\left(M^{\prime}\right) \equiv E(\tilde{B} \mid E=I-S)$. These expectations reflect only the information available to investors: the distribution of $\tilde{A}$ and $\tilde{B}$ and the decision to issue, which tells investors that the true values $a$ and $b$ satisfy Inequality (1).

Figures 2 and 3 display the two numerical examples presented above in the format of Figure 1 .

\section{Properties of Equilibrium}

These equilibrium conditions explain why the firm may pass up good opportunities rather than selling stock to raise funds. This occurs with probability $F(M)$. The ex ante loss in value is $\mathrm{L} \equiv \mathrm{F}(\mathrm{M}) \overline{\mathrm{B}}(\mathrm{M}) . \quad \mathrm{L}=0$ when $\mathrm{S} \geq \mathrm{I}$. Other things equal, $\mathrm{L}$ increases if $E$, the required equity issue, increases. Since $E=I-S$, the loss also increases with the required investment $I$ and decreases with slack available S. $\underline{8}$

Special cases. "Corner solutions," in which the firm always issues stock or never issues stock, are rarely encountered in this model given reasonable joint probability distributions for $\AA$ and $\tilde{B}$. This occurs because both $\AA$ and $\widehat{B}$ are random and have positive means, and because the investment decision cannot be postponed. The 


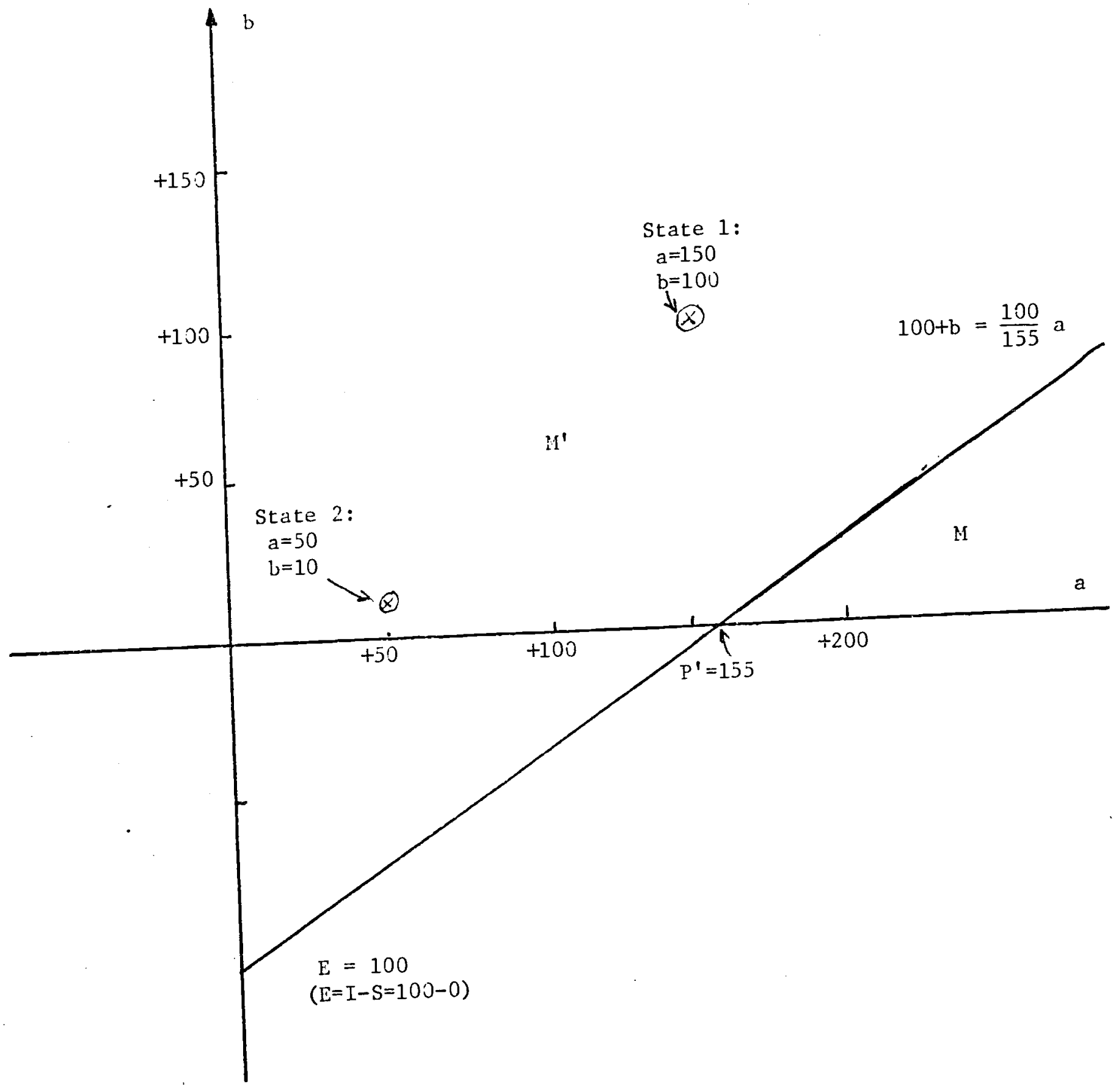

Figure 2. Solution for Example 1 from Section 2. Note Region is is empty. 


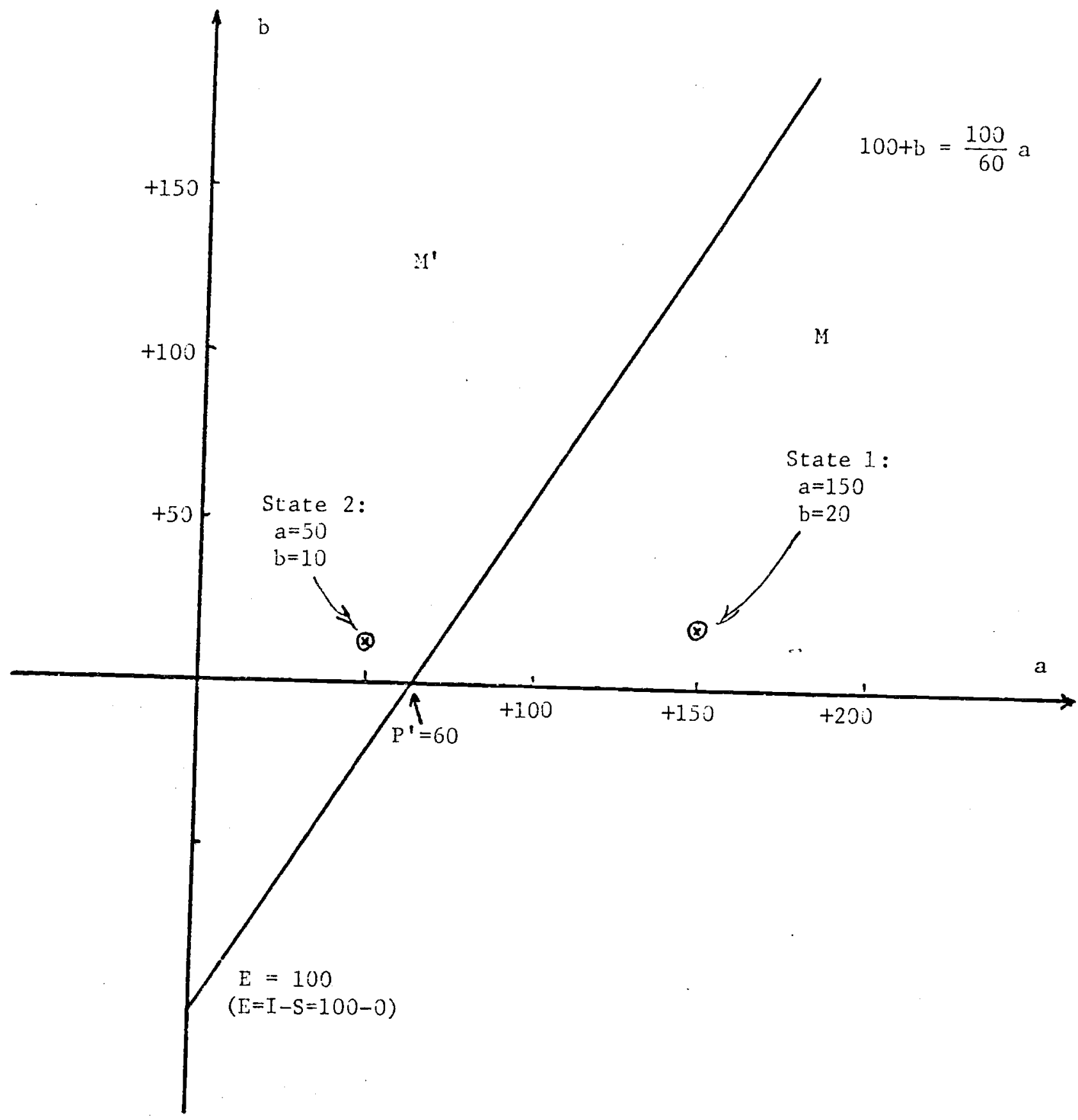

Figure 3. Solution for Example 2 from Section 2. 
following special cases do give corner solutions, however. First, if a is known by investors as well as ranacers, then stock is always issued when $b>0$, and tins $L=0$. To show tinis, :irst substitute a for $\bar{A}\left(M^{\prime}\right)$ in Equation (3)

$$
P^{\prime}=S+a+\bar{B}\left(A^{\prime}\right)
$$

Since $\bar{B}\left(M^{i}\right) \geq 0, P^{\prime} \geq S+a$. The firm will issue stock if

$$
E\left(\frac{E+a}{P^{\prime}}\right)<E+b \quad .
$$

This condition must be satisfied if $b \geq 0$, because $(S+a) / P^{\prime} \leq 1$. The firm will issue whenever $b>0$, and $P^{\prime}=s+a+\bar{B}$.

Thus differential information restricted to investment opportunities never prevents a stock issue. The terms of sale nay be favorable to the firm (if $b>\bar{B}$ ) or unfavorable (if $b<\bar{B}$ ), but even in the latter case the firm is better off issuing than losing the project entirely. Second, if the firm nas no investment opportunities $(\hat{B}=0$ in all states of the world), things break down totally: stock is never issued, except possibly when $a$ is at a definite lower bound. Let $a_{\min }$ denote a lower bound, and suppose that $P^{\prime}=a_{\text {min }}+S$. With $b=0$, the firm never issues if $a>a_{\text {min' }}$ because then

$$
E\left(\frac{S+a}{P^{\prime}}\right)>E
$$

Compare Inequality (1). On tive other hand, $P^{\prime}>a_{\text {min }}$ leads to contradiction. If $\mathrm{P}^{\prime}=a_{\text {min }}+\mathrm{S}+\mathrm{e}$, with $\mathrm{e}>0$, the firm issues 
only if $a<a_{\text {min }}+e$. Therefore $\bar{A}\left(M^{\prime}\right)<a_{\text {min }}+e$, and $P^{\prime}>S+\bar{A}\left(M^{\prime}\right)$ which violates Eq. (2).

If $b$ is positive and investors know its value, the firm will issue and invest in at least some states where $a>a_{m i n}$. It may issue in all states--that is, if $b$ is large enough and the distribution of $\tilde{A}$ tight enough, it may issue even if a is at the upper bound of the distribution of $\tilde{A}$.

One insight of this model is that you need differential information about both $\tilde{A}$ and $\tilde{B}$ in order to get interesting solutions. Without $\widetilde{B}$, stock is never issued except when $a=a_{m i n}$. Without $\tilde{A}$, stock is always issued when $b \geq 0$.

Issuing stock always reduces stock price. In this model, the decision to issue stock always reduces stock price, unless the issue is a foregone conclusion. That is, $P^{\prime} \leq P$.

Let $a *$ be the breakeven level of a, such that the firm is just indifferent to issuing or not issuing. Of course $a^{*}$ depends on $b$. From Eq. (1a),

$$
a^{*}+S=P^{\prime}(1+b / E)
$$

Note that $\bar{A}(M)+S>a^{*}+S$, because any $a<a *$ would lead the firm to issue $\left(a<a^{*}\right.$ implies $\left.a *+S<P^{\prime}(1+b / E)\right)$. Since $P=\bar{A}(i I)+S, \quad P>P^{\prime}(1+b / E)$. Since $b>0, P^{\prime}(1+b / E) \geq P^{\prime}$ and $\mathrm{P} \geq \mathrm{P}^{\prime}$. 
Numerical Solutions

The key to a numerical solution is of course $P^{\prime}$ : once we know it, we can use Eq. (2) to separate regions $M^{\prime}$ and $M$. Unfortunately we cannot guarantee a unique $P^{\prime}--i t$ depends on the joint probability distribution of a and $b .9 /$ Nor can we give a more specific analytical expression for $\mathrm{P}^{\prime}$, although calculating $P^{\prime}$ by numerical methods is not difficult. The method we have used is:

1. Start by setting $P^{\prime}=S+\bar{A}+\bar{B}$. Thịs assumes the firm always issues stock if $b>0$.

2. Then determine the regions $M$ and $M^{\prime}$ assuming the firm faces this trial value for $\mathrm{P}^{\prime}$ and acts in the old stockholders' interest.

3. Calculate a new trial value of $P^{\prime}=S+\bar{A}\left(M^{\prime}\right)+\vec{B}\left(M^{\prime}\right)$ based on the regions $M$ and $M^{\prime}$ from step 2 .

4. Continue until $\mathrm{P}^{\prime}$ converges.

This procedure gives the highest equilibrium $\mathrm{P}^{\prime}$. We have found this to be a unique solution for joint lognormal distributions of $\tilde{A}$ and $\tilde{B}$, and also for joint normal distributions truncated to exclude negative As and ßs.

Table 1 illustrates the results obtained in extensive numerical experiments. $10 /$ It shows $L$, loss in market value at $t=-1$, as a percent of $\bar{B}$, the average NPV of the investment opportunity. It also shows $F\left(M^{\prime}\right)$, the probability the firm will issue stock. $\AA$ and $\tilde{B}^{\prime}$ are assumed joint lognormally distributed. Note that:

a. Increasing slack reduces $L / \vec{B}$ and increases $F\left(M^{\prime}\right)$.

b. Increasing project NPV $(\bar{B} / I)$ reduces $L / \bar{B}$.

c. Increasing the required investment $I$ increases the loss of 
TABLE 1

Calculated Losses in Market Value

When $\widetilde{A}$ and $\widetilde{B}$ are Joint Lognormally Distributed

$$
\begin{aligned}
& \text { Assumptions: } \bar{A}=100 \\
& \sigma_{\mathrm{A}}=10 \text { or } 100 \\
& \overline{\mathrm{B}}=1 \text { or } 10 \\
& \sigma_{\mathrm{B}}=10 \\
& I=10 \text { or } 100 \\
& S=0,50,90 \text { or } 100 \text { percent of I } \\
& \widetilde{A} \text { and } \widetilde{B} \text { are independent }
\end{aligned}
$$

\begin{tabular}{|c|c|c|c|c|c|}
\hline \multirow{2}{*}{$S$} & \multirow{2}{*}{$\bar{B} / I$} & \multicolumn{2}{|c|}{$I=10$} & \multicolumn{2}{|c|}{$I=100$} \\
\hline & & $\sigma_{\mathrm{A}}=10$ & $\sigma_{A}=100$ & $\sigma_{A}=10$ & $\sigma_{A}=100$ \\
\hline \multirow[t]{2}{*}{0} & .01 & $\begin{array}{l}99.8 \\
(0.1)\end{array}$ & $\begin{array}{l}100- \\
(0+)\end{array}$ & $\begin{array}{l}98.5 \\
(1.2)\end{array}$ & $\begin{array}{l}99.9 \\
(0.1)\end{array}$ \\
\hline & .10 & $\begin{array}{c}17.8 \\
(68.4)\end{array}$ & $\begin{array}{l}97.8 \\
(1.6)\end{array}$ & $\begin{array}{c}2.8 \\
(34.1)\end{array}$ & $\begin{array}{c}68.8 \\
(23.0)\end{array}$ \\
\hline \multirow{2}{*}{50} & .01 & $\begin{array}{l}94.1 \\
(3.2)\end{array}$ & $\begin{array}{l}100- \\
(0+)\end{array}$ & $\begin{array}{c}68.7 \\
(21.7)\end{array}$ & $\begin{array}{l}97.1 \\
(2.1)\end{array}$ \\
\hline & .10 & $\begin{array}{c}5.1 \\
(37.0) \\
\end{array}$ & $\begin{array}{r}84.4 \\
(11.2) \\
\end{array}$ & $\begin{array}{c}0.4 \\
(98.6)\end{array}$ & $\begin{array}{c}39.4 \\
(51.7)\end{array}$ \\
\hline \multirow{2}{*}{90} & .01 & $\begin{array}{c}19.9 \\
(65.2)\end{array}$ & $\begin{array}{l}97.0 \\
(1.9)\end{array}$ & $\begin{array}{c}5.7 \\
(85.8)\end{array}$ & $\begin{array}{c}65.0 \\
(25.9)\end{array}$ \\
\hline & .10 & $\begin{array}{c}0.1 \\
(99.5)\end{array}$ & $\begin{array}{c}18.7 \\
(70.5)\end{array}$ & $\begin{array}{c}0+ \\
(100--)\end{array}$ & $\begin{array}{c}5.1 \\
(89.6)\end{array}$ \\
\hline \multirow[t]{2}{*}{100} & .01 & $\begin{array}{c}0 \\
(0)\end{array}$ & $\begin{array}{c}0 \\
(0)\end{array}$ & $\begin{array}{c}0 \\
(0)\end{array}$ & $\begin{array}{c}0 \\
(0)\end{array}$ \\
\hline & .10 & $\begin{array}{c}0 \\
(0)\end{array}$ & $\begin{array}{c}0 \\
(0)\end{array}$ & $\begin{array}{c}0 \\
(0)\end{array}$ & $\begin{array}{c}0 \\
(0)\end{array}$ \\
\hline
\end{tabular}

Loss in Market Value as Percent of $\bar{B}$

Parentheses contain probability that firm vill issue. Source: Majluf (1978), Table 4, p. 167 and Table 6, p. 169. 
value $\mathrm{L} / \overline{\mathrm{B}}$ when $\overline{\mathrm{B}}$ is held constant. For example, compare

$\mathrm{L} / \overline{\mathrm{B}}$ for $\mathrm{I}=10, \overline{\mathrm{B}} / \mathrm{I}=.10$ with $\mathrm{L} / \overline{\mathrm{B}}$ for $\mathrm{I}=100, \overline{\mathrm{B}} / \mathrm{I}=.01$

$(\bar{B}=1$ in each case $)$.

d. Reducing the standard deviation of assets in place $\sigma_{\mathrm{A}}$ reduces the loss in value. (We showed above that $\mathrm{L}=0$ when $\left.\sigma_{A}=0.\right)$

We also experimented with the standard deviation of $B$ and the correlation of $\widetilde{A}$ and $\widetilde{B}$, but found no uniform effects.

Table 2 shows calculated values for $L / \bar{B}$ and $F\left(M^{\prime}\right)$ for less extreme parameters. $\bar{A}$ is fixed at 100. Suppose the calendar time between $t=-1$ and 0 or 0 and +1 is 4 years. It is not unusual to find firms growing 10 percent per year, so required investment is set at $I=40$, with $N P V=+10$. The correlation between $\widetilde{A}$ and $\widetilde{B}$ is t0.7--a high correlation between the values of a firm's asset-in-place and growth opportunities seems realistic. Final1y, the standard deviations of $\tilde{A}$ and $\tilde{B}$ are set at 50 percent of $A$ and $B$.

The losses in value shown in Table 2 are clearly economically significant.

\section{EXTENSIONS AND IRPLICATIOAS}

Having explained our model formally, we can now turn to possible extensions and qualifications. We also discuss broader issues, for example, the implications of managers' superior information for capital structure and dividend policy.

Easy Ways Out

There is of course an easy way out--an easy way to avoid any loss of market value: just issue stock at $t=-1$, when managers and the market share the same information. That is one lesson of our model. 
TABLE 2

Calculated Losses in Market Value

$$
\begin{array}{lll}
\text { Assumptions: } & \overline{\mathrm{A}}=100 & \sigma_{\mathrm{A}}=50 \\
& \overline{\mathrm{B}}=10 & \sigma_{\mathrm{B}}=5 \\
& \mathrm{I}=40 & \\
& \text { correlation of } \tilde{\mathrm{A}}, \tilde{\mathrm{B}}=+0.7 \\
& \\
& \\
& \\
&
\end{array}
$$

$\begin{array}{ccc}\begin{array}{c}\text { S/I } \\ \text { (percent) }\end{array} & \begin{array}{c}\text { L/B, loss } \\ \text { in value }\end{array} & \begin{array}{c}\text { P(M') } \\ \text { probability } \\ \text { issue and } \\ \text { investment }\end{array} \\ 0 & 63.2 & 48.0 \\ 25 & 29.7 & 78.0 \\ 50 & 7.2 & 95.0 \\ 75 & 0.2 & 99.8 \\ 100 & 0.0 & 100.0^{\text {a }} / \\ & & \\ \text { necessary. } & & \\ \text { Majluf (1978), Table 18, p. 183. } & \end{array}$


If managers know more than the market does, firms should avoid situations in which valuable investment projects have to be financed by stock issues. Having slack solves the problem, and one way to get slack is to issue stock when there is no differential information.

This is not an easy way out, however, if the information differential is permanent. Suppose managers are always one period ahead of the market. At $t=-1$, for example, managers would know $\bar{A}$ and $\bar{B}$, but investors would not. Investors would see $\bar{A}$ and $\bar{B}$ as random variables.

Table 3 shows who knows what, when. Values of assets-in-place and the investment opportunity are now subscripted for time. Note that $a_{-1}=\bar{A}_{0}, a_{-2}=\bar{A}_{-1} ; b_{-1}=\bar{B}_{0}, b_{-2}=\bar{B}_{-1}$, etc. The table assumes that there is only one investment opportunity which must be taken at $t=0$ or 1ost. Also, investors "catch up" to managers at $t=+1$. Thus $\bar{A}_{1}=a_{1}$ and $\bar{B}_{1}=b_{1}$.

Assume the firm has insufficient slack to undertake the project, that the amount of slack is fixed unless equity is issued to increase it, and that the investment required to undertake the project is known.

Consider the decision to issue $E=I-S$ dollars of stock at $t=-1$. If the firm does not issue, its true market value, known to managers, is $v_{-1}$ (no issue) $=a_{-1}+b_{-1}+S-L$. If it does issue, $v_{-1}($ issue) $=$ $a_{-1}+b_{-1}+S+E$. A stock issue of $E=I-S$ at $t=-1$ thus has a net value of $L$, because it guarantees the firm will invest if $b_{0}>0$.

Now redefine the value of assets-in-place at $t=-1$ as $a_{-1}^{*} \equiv_{-1}+b_{-1}-$ L. Let $b_{-1}^{*} \equiv L . b_{-1}^{*}$ is the NPV of investing $E=I-S$ in cash or marketable securities--i.e., in slack. Managers know the payoff of investing in slack but investors do not. $L$ is a random variable from their point of view, because its value depends on 
TABLE 3

Information Available to Managers and the Market When the Market is Always

One Period Behind

Information

Available to:

...

$-2$

$-1$

0

$+1$

Managers

$$
\cdots
$$

a

Market

$$
\ldots
$$

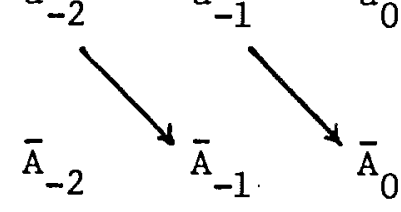

$a_{1}$

$\ldots$

Managers

$$
\text { .. }
$$

$$
\text { b }-2
$$

$-2$

Market

$$
\text { .. }
$$

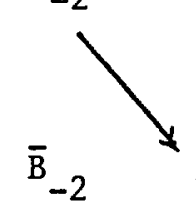<smiles>[10BH][10BH]</smiles>

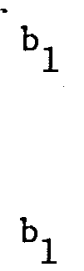


$a_{-1}$ and $b_{-1}$, which they will not know until $t=0$. However, investors do know the distributions of $a_{-1}$ and $b_{-1}$ and therefore the distribution of $L$. That is, they know the joint distribution of $\tilde{A}_{-1}^{* *}$ and $\widetilde{B}_{-1}^{* *}$.

This brings us back to the same problem we started with in section 1 . We have "assets-in-place" worth $a_{-1}^{*}=a_{-1}+b_{-1}-L$ and an "investment opportunity" worth $\mathrm{b}_{-1}^{*}=\mathrm{L}$. The joint probability distribution of these values is determined by the firm's actual assets, investment opportunities and equilibrium issue-investment strategy. At $t=-1$, the firm's decision to issue and the price investors are willing to pay are govemed by Eqs. (1) and (2) with the appropriate starred values inserted. These equations would also apply in $t=-2, t=-3$, etc., when expressed in terms of appropriatelydefined variables.

We will not here pursue analysis of the optimal issue strategy in this dynamic setting. However, we have shown that the problems addressed in this paper do not go away when the firm has no immediate real investment opportunity. Given differential information, a firm with valuable future real investment opportunities is always better off with slack than without it. Moreover, it should build up slack through retention rather than stock issues. This is consistent with actual retention policies of most public firms, which limit dividends so that they will rarely have to go to the market for fresh equity.

Thus we add one item in favor of the list of possible arguments for low dividend payout. On the other hand, dividends would alieviate the problems posed in this paper if they help signal the true value of $\tilde{\AA}$, thus reducing $\sigma_{A}$. This is not necessarily an argument for high average payout. It does support positive payout policies with a high correlation of changes in dividends and $\tilde{A}$. 
This could explain why dividend payments respond to changes in earnings, not market value. Earnings reflect the performance of assets in place.

At this point we revert to our original three-date model, in which differential information is important only at $t=0$.

\section{Debt Policy}

Another easy way out is to issue debt rather than equity. If the firm can issue default-risk free debt, our problem disappears: the firm never passes up a positive-NPV investment.

If it can only issue risky debt, our problem is only alleviated: the firm sometimes passes up positive-NPV investments, but the opportunity loss is less with debt than with equity financing. The general rule is : better to issue safe securities than risky ones. 
This requires more careful discussion. Assume the required investment $I$, can be financed with debt, $D$, or equity $E$. These are two distinct policies announced at $t=-1$ and adhered to in $t=0$. That is, the firm must choose debt or equity before managers know the true values $a$ and $b$. (If they could observe $a$ and $b$ and then choose, we would have a much more difficult problem, for their choice would give an additional signal to investors.) 11 l

The firm issues and invests if $\mathrm{v}^{\mathrm{old}}$, the "intrinsic value" of the old stockholders' equity, is higher with the issue than without it. If it does issue, $v^{\text {old }}$ equals the total firm value less the value of the newly-issued securities.

Suppose equity is issued. Then $v^{\text {old }}=a+b+I-E_{1}$, where $E_{1}$ is the newly issued shares' market value at $t=+1$, when investors learn a and $b$. The issue price of these shares is just $E=I-S$ at $t=0$. Thus $v^{\text {old }}=s+a+b-\left(E_{1}-E\right)=s+a+b-\Delta E ; \Delta E$ is the new share-holders' capital gain or loss when the truth comes out at $t=+1$, conditional on the firm's issue of shares at $t=0$.

The firm will issue and invest only if

$$
S+a<s+a+b-\Delta E
$$

or if $\mathrm{b}>\triangle \mathrm{E}$. The investment's NPV must exceed the capital gain on newly-issued shares. (Note: $\Delta E$ may be positive or negative. At equilibrium investors expect it to be zero. The firm knows the true value.) 
If debt is issued, we follow exactly the same argument, with $D$ and $D_{1}$ substituted for $E$ and $E_{1}$, and reach the same conclusion: the firm will issue and invest only if $\mathrm{b}$ exceeds $\Delta \mathrm{D} \equiv \mathrm{D}_{1}-\mathrm{D}$. Of course if the debt is defaultrisk free, $\Delta D=0, \underline{12 /}$ and the firm always issues and invests when $b>0$. Thus the ability to issue risk-free debt is as good as financial slack. If the debt is not default-riș free, $\Delta \mathrm{D}$ may be positive or negative. It will have the same sign as $\Delta E$, but its absolute value will always be less. $13 /$

Now compare the issue-invest decisions for debt vs. equity financing. Since $b \geq 0$, the firm will always invest when $\Delta D$ and $\Delta E$ are negative. Suppose $\Delta D$ and $\Delta E$ are positive (good news in store for investors at $t=t+1$ ). If the firm is willing to issue equity and invest, it is also willing to issue debt $(\Delta \mathrm{D} \because \Delta \mathrm{E}$, so $\mathrm{b} \geq \Delta \mathrm{E} \Rightarrow \Delta \mathrm{b}>\Delta \mathrm{D})$. But debt is issued in some states where equity is not $(\Delta D \leq b<\Delta E)$. Thus the ex ante value of tine firm is higher under the debt-financing policy, because the loss in market value (L) due to under-investment is less.

This may explain why many firms seem to prefer internal financing to financing by security issues and, when they do issue, why they seem to prefer bonds to stock. This could be interpreted as managerial capitalism--an attempt by managers to avoid the discipline of capital markets and to cut the ties that bind managers' to stockholders' interests. In our model, this behavior is in the stockholders' interest. 
Acting in All Stockholder's Interests

Stockholders are better off ex ante, and on average, ex post, $\underline{14}$

if managers maximize $\mathrm{V}$ rather than $\mathrm{v}^{\text {old }}$. If they act in the interests

of all stockholders at $t=0$, they always issue stock when $b>0$.

Therefore $\mathrm{L}=0$. Stockholders would vote for this policy at $t=-1$ even

though it would sometimes work against their interest at $t=0$.

The obvious difficulty comes when new--or old--stockholders at tempt to verify managers' adherence to the policy ex post. The temptation to depart from it is particularly strong when stock is issued only once and reputation has no value for the future. In practice, there may be conventions or institutional arrangements designed to prod managers to take the long view.

Asset Sale and Repurchase of Shares

Suppose the firm already has invested in two assets worth $a_{1}$ and $a_{2}$. It is $t=0$, and the market knows the distributions $\widetilde{A}_{1}$ and $\widetilde{\mathrm{A}}_{2}$ but not $a_{1}$ and $a_{2}$. Also, asset 1 can be sold for $C$.

First assume that selling the first asset requires the firm to use the proceeds $\mathrm{C}$ to repurchase shares. This disinvest-repurchase decision would be made by exactly the same reasoning as the issue-invest decision discussed above. The equilibrium conditions are exactly the same except for changes of sign. 
However, firms are rarely, if ever, forced to use the proceeds of an asset sale to repurchase shares. If the proceeds can be held as cash until $t=1$, then the decision to repurchase signals investors that the firm's remaining asset is undervalued at $\bar{A}_{2}$. If the firm insists on repurchasing, it derives $\mathrm{P}^{\prime}$ to $\mathrm{A}_{2 \max }$, the upper bound of the distribution of $\mathrm{A}_{2}$. Equilibrium with repurchase could occur only when $a_{2}=A_{2 \max }$ and $a_{1} \leq C$. (If there's no upper bound, there's no equilibrium.) In this case, where the only reason for repurchasing is to take advantage of investors who sel1, repurchasing wolld be extremely rare.

The difficulty here is that repurchase may reward faithful stockholders at the expense of unfaithful ones. A pro rata repurchase could avoid the problem, but in that case, the firm might just as well pay a cash dividend. A pro rata repurchase is taxed like a cash dividend.

Now turn back to the case in which the firm has one asset in place, and one investment opportunity, with intrinsic values $a$ and $b$ at $t=0$. However, the asset-in-place can be sold.

If it can be sold for $a$, without affecting $b$, then the problems addressed in this paper evaporate. $15 /$ If the investment opportunity has positive NPV $(b>0)$; the firm sells the asset-in-place. If the proceeds cover the investment required $(a \geq I)$, it goes ahead. But also goes ahead if a $<I$, because selling the asset-in-place reveals its true value. As we showed above, differential information restricted to investment opportunities never prevents a stock issue. 16 
This leads us to another "easy way out." The firm can simply spin off its asset-in-place as a separately-financed company. In our model, stockholders are better off ex ante holding holding two firms rather than one, providing that the spinoff does not reduce the values of the distributions $\tilde{A}$ and /or $\tilde{B}$.

\section{Hergers}

Our model's main message is this: given differential information, a firm with insufficient financial slack may not undertake all valuable investment opportunities. Thus a firm that has too little slack increases its value by acquiring more.

One way to do this is by merger. A merger always increases value when one firm's surplus slack fully covers the other's deficiency. $17 /$

But the same conditions that create this potential gain will complicate the merger negotiations and in some cases rule out any possibility of their successful completion. Consider a firm with an existing business, a good investment opportunity, but insufficient slack to pay for it. It seeks a merger with a cash-rich firm. However, the would-be buyer only knows the distributions $\tilde{A}$ and $\widetilde{B}$, not the true values $a$ and $b$.

Let $Q^{\prime}$ be the proposed merger price. That is, if the merger offer is accepted, the shareholders of the cash-poor firm receive $Q^{\prime}$ in cash. If the offer is turned down, that firm's shareholders forego the investment and are left with $S+a$. Thus, given $a$ and $b$, the offer will be accepted if $Q^{\prime}>S+a$. But the cash-rich firm will only offer $Q^{\prime}=S+\bar{A}\left(N^{\prime}\right)+\bar{B}\left(N^{\prime}\right)$, where $\bar{A}\left(N^{\prime}\right)$ and $\bar{B}\left(N^{\prime}\right)$ are the expectations of $\tilde{A}$ and $\tilde{B}$ conditional on observing that the cash-poor firm is willing to go through with the deal. Under these assumptions, the merger would never occur. The cash-poor firm can always do better by issuing stock directly to investors, 
because $P^{\prime}$ always exceeds $Q^{\prime} . \underline{18 /}$

The decision to sell shares always carries negative information, regardless of whether the shares are sold to investors generally or to a specific acquiring firm. The buyer or buyers discount the shares so that cost equals expected payoff. If the firm issues $E=I-S$, old shareholders retain a stake, but if their firm is sold they are completely disengaged from it. The decision to sell all of the firm via merger, rather than issue the fraction $\mathrm{E} /\left(\mathrm{P}^{\prime}+\mathrm{E}\right)$, drives down market price below $\mathrm{P}^{\prime}$, because the firm has chosen to sell more stock than absolutely necessary to cover the investment I. (We assume that (1) the acquiring firm's slack exceeds the selling firm's deficiency ( $(-S)$, (2) the acquiring firm has other assets, and (3) everyone knows what these assets are worth.)

Negotiated mergers thus seem to be ruled out regardless of financing, because the cash-poor firm can always do better by issuing stock. How can mergers be explained under the premises of this paper?

There are two possible explanations. First, there may be partial or total disclosure of internal information during negotiation. $\frac{19 /}{}$ Second, the merger may go through if the buyer rather than the seller takes the initiative. In our mode1, firms with plenty of slack should seek out acquisition targets which have good investment opportunities and limited slack, and about which investors have limited information. Such firms sell at a discount from their average potential value $\bar{A}+\bar{B}+S . \stackrel{20}{ }$ A tender offer made directly to the slack-poor firm's shareholders, at a price above $\bar{A}+\bar{B}+S-L$ but below $\bar{A}+\bar{B}+S$, makes both the bidder and the target's shareholders better off ex ante, although neither buyer nor sellers know the true value $a+b+s$. 
A tender offer conveys no bad news about $a+b+S$ so long as the target's management are not accomplices. Perhaps this explains why most mergersare initiated by buyers. A firm that actively seeks to be bought out may end up a wallflower. The more actively management seeks to sell, the less an outsider will assume their firm is worth.

\section{CONCLLSION}

We have presented a model of the issue-investment decision when the firm's managers have superior information. We hesitate to state definite empirical predictions, having ignored taxes, transaction costs, agency costs, and other things the decision may depend on. We can nevertheless sum up by reviewing the model's most interesting properties.

1. It is always better to issue safe securities than risky ones. Firms should go to bond markets for external capital, but raise equity by retention if possible. That is, a policy of external financing using debt is better than one using equity.

2. The firm should not pay a dividend if it has to recoup the cash by selling stock or some other risky security. Of course dividends could help convey managers' superior information to the market. Our model suggests a policy under which changes in dividends are highly correlated with managers' estimate of the value of assets in place. $\frac{21 /}{}$

3. Firms whose investment opportunities outstrip operating cash flows, and which have used up their ability to issue low-risk debt, may forego good investments rather than issue risky securities to finance them. This is done in the existing stockholders' interest. However, stockholders 
are better off ex ante--i.e., on average--when the firm carries sufficient financial slack to undertake good investment opportunities as they arise. The ex ante loss in value increases with the size of the required equity issue. Thus, increasing the required investment or reducing slack available for this investment also increases the ex ante loss. In addition, numerical simulations indicate the loss decreases when the narket's uncertainty about the value of assets in place is reduced, or when the investment opportunity's expected NPV is increased.

4. Firms can build up financial slack by restricting dividends when investment requirements are modest. The cash saved is held as marketable securities or reserve borrowing power.

The other way to build slack is by issuing stock before cash is required for investment. Firms would try to make such precautionary issues in periods when managers' information advantage is snall; they would definitely issue in periods where managers have no information advantage. However, we have not derived a generally optimal dynamic issue strategy.

5. When managers have superior information, and stock is issued to finance investment, stock price will fall.

6. A merger of a slack-rich and slack-poor firm increases the firms' combined value. However, negotiating such mergers will be hopeless unless the slack-poor firns' managers can convey their special information to the prospective buyers. If this information cannot be conveyed (and verified), slack-poor firms will be bought out by tender offers made directly to their shareholders. 
of course the six items stated just above depend on the specific assumptions of our model and may not follow in other contexts. We have only explored one of many possible stories about corporate finance. A full description of corporate financing and investment behavior will no doubt require telling several stories at once.

A more comprehensive theory of financing policy would be a good initial target for further research. Our model supplies a rationale for debt financing even in the absence of taxes. On the other hand, a policy that relies too heavily on debt increases the likelihood of bankruptcy costs and agency costs or problems of moral hazard. $\frac{22 /}{}$ Firms may arrive at their optimal debt policies by balancing these considerations. $\frac{23 /}{}$ 
1. Sloan School of Management, Massachusetts Institute of Technology, and National Bureau of Economic Research; Universidad Catolica de Chile. This paper draws on Majluf [12] and an earlier (1978) joint working paper with the same title as this one. The delay in revision is the senior author's fault.

2. We could interpret our time subscript not as calendar time, but just the state of information available to the firm and market.

3. That is, managers may have inside information about the firm, but not about the market or the economy.

4. An analogy may help make this clear. Think of a share of IBM stock on January $1(t=-1)$. $\tilde{A}$ could be the unknown distribution of the February 1 price, a the actual price on February $1(t=0)$. However a fur trapper snowed in on the upper MacGregor River might not learn the February 1 price until March $1(t=+1)$.

5. Rights issues resolve the conflict of interest only if old stockholders can be compelled to exercise their rights and hold the newly-issued shares.

6. However, Grossman's recent paper [8] on product warranties is worth noting because his underlying problem is like ours. There are also tempting analogies between our paper and the literature on credit rationing. See, for example, Jaffee and Russel1 [10] and Stiglitz and Weiss [17, 18].

7. Downs and Heinkel [5] contains empirical evidence supporting the LelandPyle analysis.

8. A formal proof is given in Majluf [12], Appendix 2, pps. 286-290. See also pps. 142-143.

9. Majluf [12] shows that at least one equilibrium $P^{\prime}$ exists if the firm issues stock. See his Appendix 1, pps. 279-285.

10. Reported in Majluf [12] pps. 165-183. 
11. This problem is addressed in Rendleman's paper [13]. As noted above, he does not devise a full equilibrium solution for it.

12. That is, the change in the debt value at $t=1$ is independent of the firm-specific information revealed to investors at that time. other things, such as a general shift in interest rates, may change debt value, but that is irrelevant here.

13. We know this from option-pricing theory. See, for example, Galai and Masulis [6].

14. Old stockholders are always better off ex post if the firm is sure to have positive NPV opportunity, i.e., if $b$ is always positive. In this case, the firm always issues stock, so $P^{\prime}=V_{-1}=\bar{A}+\bar{B}$. If managers act in old stockholder's interest at $t=0$, as we have assumed, then $\mathrm{P}^{\prime}<\mathrm{V}_{-1}=\overline{\mathrm{A}}+\overline{\mathrm{B}}-\mathrm{L}$.

15. What if only part of the asset-in-place can be sold? If it can be sold at intrinsic value, the firm treats the proceeds as additional slack and looks again at its issue-invest decision.

16. What if the asset in place can only be sold at a discount? What if the potential buyer does not know its true value? What if sale of the asset in place reduces $b$ ? These questions are worth exploring.

17. If the merged firms' total slack does not fully cover their investment requirements, the merger may or may not increase value. See Majluf [12], pps. 239-256. 
18. A proof follows. Define $a *\left(N^{\prime}\right)$ as the breakeven value of $a$, the value at which the cash-poor firm is just indifferent to being acquired at the equilibrium price $Q^{\prime}$. Note that $Q^{\prime}=a^{*}\left(N^{\prime}\right)+S$. Refer again to (1a), the requirement for the firm to issue stock:

$$
\frac{E}{P^{1}}(S+a)<E+b .
$$

If $P^{\prime}$ were equal to $Q^{\prime}$, the firm would issue and invest at $a *\left(N^{\prime}\right)$ for any $b>0$. That is, if

$$
\begin{gathered}
P^{\prime}=Q^{\prime}=S+a *\left(N^{\prime}\right), \\
\frac{E}{P^{\prime}}(S+a)=\frac{E}{S+a *\left(N^{\prime}\right)}\left(S+a *\left(N^{\prime}\right)\right)=E<E+b .
\end{gathered}
$$

Thus $a^{x}\left(M^{\prime}\right)$, the breakeven value of $a$ at which the firm is just willing to issue stock, exceeds $a^{*}\left(N^{\prime}\right)$ for any $b>0$. $\bar{A}\left(M^{\prime}\right)+\bar{B}\left(M^{\prime}\right)>\bar{A}\left(N^{\prime}\right)+\bar{B}\left(N^{\prime}\right)$ and $P^{\prime}>Q^{\prime}$.

19. The cash-poor firm would prefer to negotiate with a firm that is not a competitor. A competitor might back out of the negotiations and take advantage of information acquired in them. This hazard is less in a "conglomerate" merger.

20. We assume the target firm has not yet declared its issue-invest decision.

21. However, there is no mechanism in our model to insure that such a policy would be followed at $t=0$ even if announced at $t=1$.

22. Agency costs and moral hazard problems exist only when managers have superior information. 
23. Chapter 6 of MajluF́'s thesis [12] has extended our model to cover several cases of mixed debt and equity financing. 


\section{REFERENCES}

1. Akerlof, G.A., "The Market for 'Lemons:' Quality Lncertainty and the Market Mechanism," Quarterly Journal of Economics, Vol. 84 (August 1970),
pps. 488-500.

2. Bhattacharya, S., "Imperfect Information, Dividend Policy and the 'Bird in the Hand Fallacy,'" Bell Journal of Economics, Vol. 10
(Spring 1979), pps. 259-270.

3. , and Ritter, J.R., "Innovation and Communication: Signalling With Partial Disclosure," Working Paper, Stanford University, 1980.

4. Campbell, T.S., "Optimal Investment Financing Decisicns and the Value of Confidentiality," Journal of Financial and Quantitative Analysis,

5. Downes, D.H. and Heinkel, R., "Signalling and the Valuation of Unseasoned New Issues," Working Paper, Institute of Business and Economic Research, University of California, Berkeley, December 1979.

6. Galai, D. and Masulis, R., "The Option Pricing Model and the Risk Factor of Stock," Journal of Financial Economics, Vol. 3 (January-
March 1976), pps. 53-82.

7. Grossman, S.J., "An Introduction to the Theory of Rational Expectations Under Asymmetric Information," Review of Economic
Studies 48 (1981), pps. 541-559.

8. , "The Role of Warranties and Private Disclosure About Product Quality," Working Paper, Rodney L. White Center for Financial Research, University of Pennsylvania, October 1980.

9.

Bids in Situations Hart, O.D., "The Allocational Role of Takeover 36 (May 1981), pps. 253-270.

10. Jaffee, D. and Russel1, T., "Imperfect Information, Uncertainty and Credit Rationing," Quarterly Journal of Economics, Vol. 90 (November
1976), pps. 651-666.

11. Leland, H. and Pyle, D., "Information Asymmetries, Financial structure and Financial Intermediation, "Journal of Finance, Vol. 32 (May 1977),
pps. 371-387. 
12. Majluf, N.S., "Study on Mergers: A Rationale for Conglomerate
Mergers," Unpublished Ph.D. Dissertation, Massachusetts Institute of Technology, 1978.

13. Rendleman, R.J., "Informational Asymmetries and Optimal Project Financing," Working Paper, Duke University Graduate School of Business, November 1980.

14. Ross, S.A., "Some Notes on Financial-Incentive Signalling Models, Activity Choice and Risk Preferences," Journal of Finance 33 (June 1978), pps. 777-792.

15. "The Determination of Financial Structure: The Incentive-Signalling Approach," Bell Journal of Economics, 8 (Spring 1977), pps. 23-40.

16. Stiglitz, J.E., "Information and Capital Markets," Working Paper No. 678, National Bureau of Economic Research, May 1981.

17. and Weiss, A., "Credit Rationing in Markets With Imperfect Information, Part I, "American Economic Review, forthcoming.

18. , "Credit Rationing in Markets With Imperfect Information, Part II: Constraints as Incentive Devices," Princ
1980. 